\title{
Cooperative Learning: Effects of Task, Reward, and Group Size on Individual Achievement
}

\author{
Joseph D. Hagman and John F. Hayes
}

Scientific Coordination Office, Boise, Idaho

Ruth H. Phelps, Chief

Training Research Laboratory

Seward Smith, Acting Director

U.S. ARMY RESEARCH INSTITUTE FOR THE BEHAVIORAL AND SOCIAL SCIENCES

5001 Eisenhower Avenue. Alexandria, Virginia 22333-5600

Office. Deputy Chief of Staff for Personnel

Department of the Army

January 1986 